\title{
EFEKTIVITAS EKSTRAK BIJI SIRSAK TERHADAP MORTALITAS Pediculus humanus var. Capitis SECARA IN VITRO
}

\author{
Efectiviness of the extract soursop seeds on the mortality of Pediculus humanus var. \\ Capitis \\ ${ }^{1}$ Ahdiah Imroatul muflihah, ${ }^{2}$ Retno Sasongkowati \\ ${ }^{1}$ Medical Laboratory Technologist, Poltekkes Kemenkes Surabaya \\ ${ }^{2}$ Departement of Medical Laboratory Technologist, Poltekkes Kemenkes Surabaya
}

Koresponden: Ahdiah.muflihah553@gmail.com/081295983025

\begin{abstract}
Pediculosis capitis is a disorder caused by an infestation of Pediculus humanus capitis. Soursop seeds can have potential as a pediculicide. The active compounds in soursop seeds are acetogenin, annonain, flavonoids, and squamosin. This experiment aims to determine the effectiveness of soursop seed extract as a pediculicide. This research is an experimental study conducted in March-June 2017 in the parasitology laboratory of the Ministry of Health's Health Polytechnic Surabaya. This study used a sample of 160 head lice with 5 head lice in each group which were treated by spraying soursop seed extract with concentrations of 10\%, 20\%, 40\%, 60\%, 80\%, and 100\%. The results of this study indicate that the most effective concentration is $100 \%$ within 10 minutes, and the minimum concentration is $10 \%$ and $20 \%$ within 50 minutes.

Keywords : SoursopSeed Extract (Annona muricata), Head lice (Pediculus humanus var. Capitis), Pediculisida.
\end{abstract}

\begin{abstract}
ABSTRAK
Pediculosis capitis adalah gangguan yang disebabkan oleh infestasi Pediculus humanus capitis. Biji sirsak dapat berpotensi sebagai pedikulisida. Kandungan senyawa aktif dalam biji sirsak ini adalah acetogenin, annonain, flavonoid, dan squamosin. Penelitian ini bertujuan untuk mengetahui efektivitas ekstrak biji sirsak sebagai pedikulisida. Penelitian ini bersifat eksperimental yang dilakukan pada bulan Maret-Juni 2017 di Laboratorium Parasitologi Poltekkes Kemenkes Surabaya. Penelitian ini menggunakan sampel berupa kutu kepala sebanyak 160 ekor dengan masing masing kelompok 5 ekor kutu kepala yang diberikan perlakuan dengan menyemprotkan ekstrak biji sirsak dengan konsentrasi 10\%, 20\%, 40\%, 60\%, 80\%, dan 100\%. Hasil penelitian ini menunjukkan bahwa konsentrasi paling efektif ialah 100\% dalam waktu 10 menit, dan konsentrasi minimum adalah $10 \%$ dan $20 \%$ dalam waktu 50 menit.

Kata kunci : Ekstrak Biji Sirsak (Annona muricata), Kutu kepala (Pediculus humanus var. capitis), Pedikulisida.

\section{PENDAHULUAN}

Pediculus capitis merupakan gangguan pada kulit rambut kepala yang disebabkan oleh infeksi Pediculus humanus capitis. (CDC, 2012) Pada

penelitian di Bangkok tahun 2012 ditemukan 25,48\% penderita Pediculosis pada usia 3-12 tahun dan yang terinfeksi adalah pada anak perempuan saja. (Rassami \& Soonwera,
\end{abstract}


2012). Selain itu juga penelitian tahun 2012 di pesantren X di Jakarta Timur adalah $100 \%$ yaitu seluruh santri putri Tsanawiyah dan Aliyah, dan 22,22\% terinfeksi berat Pediculus humanus capitis (Alatas, 2013). Pengobatan Pediculosis ini mudah dilakukan akan tetapi reinfeksi juga mudah terjadi apabila tidak diikuti oleh perilaku hidup bersih dan sehat. Saat ini berbagai bentuk pengobatan yang umum digunakan adalah pengobatan yang berbahan dasar kimia seperti lindane, carbaryl, pyrethrin, permethrin, dan malathion, serta bahan-bahan yang tersedia di rumah, dan juga sisir kutu (Anonim, 2009, dalam Khasanah, 2014).

Pengobatan tradisional memiliki kelebihan dibanding dengan pengobatan secara kimiawi. Sehingga dapat mencari alternatif menggunakan pengobatan tradisional yaitu dengan tumbuhan dengan jenis pestisida alami, salah satunya ialah tumbuhan sirsak. Tumbuhan sirsak termasuk family annonaceae yang dapat dimanfaatkan sebagai bahan insektisida alami. Tumbuhan sirsak ini juga mengandung senyawa acetogenin, annonain, flavonoid, dan squamosin. Acetogenin berfungsi untuk menghambat ikatan $N A D H$ ubiquinone reductase (complex 1) sehingga dapat menurunkan kadar ATP pada mitokondria serangga. Maka dari itu serangga akan kehilangan nafsu makannya sehingga lambat laun akan kehilangan energi dan pernafasaan sel akan terhenti (Rosmayanti. 2014). Annonain dan Squamosin berfungsi untuk merusak bagian pencernaannya yaitu usus tengah sehingga tidak terjadi penyerapan energy (Ningsih dan Wahyuni, 2016). Isoflavon memiliki efek pada reproduksi yaitu antifertilitas sehingga dapat mencegah perkembangbiakan kutu kepala (Latifah, 2016).
Pediculus humanus capitis masih sering dijumpai di lingkungan pesantren dimana masih banyak yang terinfeksi Pediculus humanus capitis serta kebersihan masih buruk. Sehingga penelitian ini bertujuan untuk mengetahui efektivitas ekstrak biji sirsak terhadap mortalitas Pediculus humanus capitis dengan konsentrasi 10\%, 20\%, $40 \%, 60 \%, 80 \%$, dan $100 \%$ dalam waktu 10 menit, 20 menit, 30 menit, 40 menit, 50 menit, dan 60 menit.

\section{METODE}

Penelitian ini merupakan jenis penelitian eksperimen laboratorium guna untuk mengetahui efektivitas ekstrak biji sirsak terhadap mortalitas kutu kepala yang dilakukan di Laboratorium Parasitologi Jurusan Analis Kesehatan Poltekkes Kemenkes Surabaya pada bulan Maret - Juni 2017.

Populasi dalam penelitian ini ialah biji buah sirsak yang diperoleh dari pasar tradisional Kecamatan Waru pada bulan Maret - Juni tahun 2017 dan kutu kepala sebanyak 160 ekor kutu rambut yang terdapat pada pondok pesantren $\mathrm{x}$ di Kecamatan Siwalankerto, Surabaya pada bulan maret-juni 2017. Sampel pada penelitian ini ialah biji buah sirsak yang telah matang dan kutu rambut pada santriwati pondok pesantren $\mathrm{x}$ di Kecamatan Siwalankerto, Surabaya. Pengambilan sampel pada penelitian ini menggunakan teknik purposive sampling.

\section{Langkah-Langkah Penelitian}

Langkah-langkah dalam penelitian adalah dengan mengekstrasi biji sirsak yang dilakukan di Laboratorium Farmasi Universitas Airlangga dengan menggunakan metode maserasi. Pada tahap proses pengujian larutan ekstrak biji sirsak dilarutkan pada konsentrasi 10\%, 20\%, 40\%, 60\%, 80\%, dan $100 \%$. Setiap larutan akan ekstrak biji sirsak akan diletakkan pada botol 
spray dan kemudian disemprotkan pada 5 ekor kutu kepala yang terdapat pada petridisk dan masing-masing konsentrasi diuji setiap 10 menit secara bergantian selama 1 jam. Kemudian akan dilakukan dengan pencatatan hasil penelitian dan dilanjutkan dengan perhitungan presentase kematian kutu kepala dengan rumus :

$$
\% \text { kematian }=\frac{B}{A} \times 100 \%
$$

\section{Pengolahan dan analisis data}

Pengolahan dan analisis data pada penelitian ini dilakukan secara analisis deskriptif dengan disajikan dalam bentuk tabel dan dibahas dengan menggunakan narasi.

\section{HASIL}

Berdasarkan hasil penelitian pada ekstrak biji sirsak terhadap mortalitas kutu kepala semakin tinggi konsentrasi yang digunakan maka dapat efektif membunuh kutu kepala dengan cepat dari pada konsentrasi yang rendah. Perbedaan pada bahan control bahwa untuk control positif pada waktu 10 menit dapat membunuh $100 \%$ kutu kepala, dan untuk control negative tidak ada mortalitas kutu kepala pada 10 menit pertama hingga 60 menit.

\section{PEMBAHASAN}

Dari hasil penelitian dapat diketahui bahwa ekstrak biji sirsak (Annona muricata) pada konsentrasi $10 \%, 20 \%$, $40 \%, 60 \%, 80 \%$, dan $100 \%$ dapat membunuh kutu kepala secara In Vitro. Pada konsentrasi 10\% efektif membunuh kutu kepala secara $100 \%$ pada menit ke 50. Pada konsentrasi $20 \%$ efektif membunuh kutu kepala secara 100\% pada menit ke 50. Pada konsentrasi $40 \%$ efektif membunuh kutu kepala secara $80 \%$ pada menit ke 30 . Pada konsentrasi $60 \%$ efektif membunuh kutu kepala secara $100 \%$ pada menit ke 20. Pada konsentrasi $80 \%$ efektif membunuh kutu kepala secara $80 \%$ pada menit ke 10 .
Pada konsentrasi $100 \%$ efektif membunuh kutu kepala secara 100\% pada menit ke 10. Menurut WHO 2010, dikatakan efektif pada vektor mortalitas insektisida apabila $>70 \%$. Sehingga dapat dikatakan bahwa konsentrasi ekstrak biji sirsak (Annona muricata) mempengaruhi waktu kematian kutu kepala. Semakin pekat konsentrasi ekstrak biji sirsak (Annona muricata) maka semakin banyak jumlah kandungan kimianya sehingga semakin cepat waktu yang dibutuhkan dalam mematikan kutu kepala.

Biji sirsak mengandung senyawa fitokimia antara lain senyawa flavonoid, saponin, tanin dan suatu senyawa turunan bistetrahidrofuran ; acetogenin (skuamostatin $C, D$, anonain, anonasin $A$, anonin I, IV, VI, VIII, IX, XVI, skuarnostatin A, bulatasin, bulatasion, skuamon, neo desatilurarisin, neo retikulasin A, skuamosten A, asimisin, skuamosin, sanonasin, anostatin, neo anonin). ). (Rustanti, 2007, dalam Islamiarto, 2012).

Dalam penelitian ini biji sirsak akan diekstraksi dengan menggunakan metode maserasi sehingga akan mendapatkan senyawa yang dapat digunakan untuk pedikulisida antara lain acetogenin, annonain, squamosin, dan isoflavon. Acetogenin berfungsi untuk menghambat rantai ikatan $\mathrm{NADH}$ ubiquinone reductase (complex 1) sehingga dapat menurunkan kadar ATP pada mitokondria serangga. Sehingga serangga akan kehilangan energy dan pernafasan sel akan terhenti (Rosmayanti, 2014). Annonain dan squamosin berfungsi untuk merusak bagian pencernaan yaitu usus tengah sehingga tidak terjadi penyerapan energy (Wahyuni, 2016). Isoflavon memiliki efek pada reproduksi yaitu antifertilitas sehingga dapat mencegah perkembangbiakan kutu kepala. (Latifah, 2016). 
Senyawa Annonaceous acetogenin dapat mengalami perubahan struktur ketika berada pada suhu di atas $60^{\circ} \mathrm{C}$, sehingga dalam proses pengolahan biji sirsak tidak melebihi kisaran suhu tersebut guna untuk menjaga senyawa Annonaceous acetogenin di dalamnya, (Yang et al, 2010, dalam Khasanah 2014). Maka dari itu pada penelitian ini ekstrak biji sirsak (Annona muricata) menggunakan metode maserasi, dikarenakan maserasi tidak membutuhkan suhu di atas $60^{\circ} \mathrm{C}$

Berdasarkan uraian tersebut dan juga penelitian yang telah dilakukan dapat diambil kesimpulan bahwa senyawa acetogenin, annonain, squamosin, dan isoflavon yang terdapat dalam biji sirsak memang terbukti memiliki daya antikutu atau sebagai pedikulisida

\section{KESIMPULAN}

Penelitian ini dapat disimpulkan bahwa esktrak biji sirsak efektif terhadap mortalitas kutu kepala dengan konsentrasi maksimum $100 \%$ dalam waktu 10 menit sedangan konsentrasi minimum adalah $10 \%$ dalam waktu 50 menit.

\section{SARAN}

Penelitian yang telah dilakukan untuk kelanjutan penelitian ini dengan mengurangi konsentrai dan waktu penelitian dengan pengaplikasian metode yang berbeda. Serta dapat dipertimbangkan pula untuk industri sebagai anti pedikulisida dengan memberikan formulasi bahan tambahan dehingga dapat menghasilkan hasil yang optimal. Selain itu juga untuk peneliti selanjutnya dapat melihat dengan perbandingan pada konsentrasi dengan menggunakan uji statistik komparasi.

\section{DAFTAR PUSTAKA}

Alatas, S.S.S., 2013. Hubungan Tingkat

\begin{tabular}{lrr} 
Pengetahuan & \multicolumn{1}{r}{ Mengenai } \\
Pedikulosis & Kapitis dengan \\
Karakteristik & Demografi Santri \\
Pesantren & $X$, & Jakarta \\
Timur. eJournal & Kedokteran \\
Indonesia, pp.53-57. &
\end{tabular}

CDC. 2012. This is an illustration of the life cycle of Pediculus humanus var.capitis, the causal agent of Head Lice. http://www.dpd.cdc.gov/dpdx/HT ML/HeadLice.htm. Diakses : 30 Desember 2016

Islamiarto. 2012. Uji Efektifitas Pasta Biji Sirsak(Annona muricata Linn) Dalam Menekan Gall dan Populasi Nematoda (Meloidogyne spp) pada Tanaman Tomat (Lycopersicum esculentium Mill.). Skripsi. Bandung: Fakultas Pertanian Universitas Padjadjaran

Khasanah, Niswatun. 2014. Uji efektivitas air perasan daun sirsak (Annona muricata)terhadap mortalitas kutu kepala(Pediculus humanus var. capitis) secarain vitro. KTI. Surabaya : AnalisKesehatan Politeknik Kesehatan Kemenkes Surabaya.

Latifah, Nurul. 2016. Toksisitas campuran ekstrak biji alpukat (Persea Americana Mill.) dan biji sirsak (Annona muricata L.) terhadap mortalitas larva nyamuk Aedes agypti L. dan pemanfaatannya sebagai leaflet. Skripsi Jember : Program Studi Pendidikan Biologi Universitas Jember.

Rassami, W. \& Soonwera, M., 2012.Epidemiology of Pediculosis Capitis Among School Children in the Eastern Area of Bangkok, Thailand. Asian : Pac J Trop Biomed 2.

Rosmayanti, Kiki. 2014. Uji efektivitas 
ekstrak biji sirsak (Annona muricata L) sebagaima larvasida pada larva Aedes aegypti instar III/IV. Jakarta : Program Studi Pendidikan Dokter Universitas Islam Negeri Syarif Hidayatullah.

SU Ningsih, D Wahyuni, 2016. Efektivitas ekstrak serai
(Cymbopogon nardus) sebagai insektisida alami dalam mengendalikan semut hitam secara penyemprotan. Pekanbaru : Journal Al Tamimi Kesmas. 
Tabel 1.

Persentase Mortalitas kutu kepala dengan Waktu Paparan dan Konsentrasi Ekstrak Biji Sirsak yang Berbeda

\begin{tabular}{ccccccc}
\hline Konsentrasi & \multicolumn{6}{c}{ Persentase (\%) Mortalitas 5 Kutu Kepala dengan Waktu Paparan } \\
\cline { 2 - 7 } $\begin{array}{c}\text { ekstrak biji } \\
\text { sirsak (\%) }\end{array}$ & $\mathbf{1 0}$ menit & $\mathbf{2 0}$ menit & $\mathbf{3 0}$ menit & $\mathbf{4 0}$ menit & $\mathbf{5 0}$ menit & $\mathbf{6 0}$ menit. \\
\hline 10 & 0 & 20 & 60 & 60 & 100 & 100 \\
\hline 20 & 0 & 40 & 60 & 60 & 100 & 100 \\
\hline 40 & 20 & 60 & 80 & 100 & 100 & 100 \\
\hline 60 & 60 & 100 & 100 & 100 & 100 & 100 \\
\hline 80 & 80 & 100 & 100 & 100 & 100 & 100 \\
\hline 100 & 100 & 100 & 100 & 100 & 100 & 100 \\
\hline Kontrol (+) & 100 & 100 & 100 & 100 & 100 & 100 \\
\hline Kontrol (-) & 0 & 0 & 0 & 0 & 0 & 0 \\
\hline
\end{tabular}

